Ele

\title{
METODIKA TESTOVANIA NEZÁVISLOSTI MEDZI KVALITATÍVNYMI ZNAKMI
}

\author{
Alena Košt'álová*, Ol'ga Zajasenská*
}

\section{Úvod}

Ciel'om predkladaného článku je predstavit' komplexne spracovanú metodiku testovania nezávislosti medzi hodnotami dvoch kvalitatívnych znakov štatistického súboru. Táto metodika bola využitá pri spracovaní dizertačnej práce zameranej na oblast' marketingového prieskumu poštových a telekomunikačných služieb v regionálnom podnikatel'skom prostredí. Vedecký problém spracovania údajov získaných marketingovým prieskumom a následný rozbor výsledkov sa opieral o uplatnenie metodiky testovania nezávislosti medzi hodnotami dvoch kvalitatívnych znakov štatistického súboru, ktoré reprezentujú názory (odpovede) respondentov tvoriacich štatistický súbor.

\section{Metódy spracovania údajov}

Základnou úlohou spracovania údajov získaných marketingovým prieskumom je pretransformovat' získané údaje do podoby vhodnej pre analýzu za účelom riešenia výskumného problému, od čoho závisí aj výber optimálnej metódy. Výber správnej štatistickej metódy analýzy údajov závisí od viacerých faktorov ako sú: typy údajov, ktoré sa skúmajú; nezávislost' výberu, teda akým spôsobom bol zo základného súboru vytvorený výberový súbor; aký je počet premenných, ktoré sú predmetom skúmania; vel'kost' výberového súboru, teda kol'ko meraní máme k dispozícií; aké sú podmienky použitia danej metódy. Ak sú štatistické znaky štatistického súboru kvalitatívne - nominálne (slovné) a ordinárne (poradové), je to dôvod pre použitie metód induktívnej štatistiky pri triedení a kvantifikácii získaných údajov (najmä metódy testovania štatistických hypotéz).

Induktívne štatistické metódy sa členia na parametrické a neparametrické [1]:

$\checkmark$ parametrické štatistické metódy narábajú s parametrami základných súborov, pričom vychádzajú zo špecifických predpokladov o rozdeleniach pravdepodobnosti základných súborov a výberových štatistík (napr. Fisherova analýza rozptylu),

$\checkmark$ neparametrické štatistické metódy sa nespoliehajú na odhad parametrov charakterizujúcich rozdelenia premennej v základnom súbore. Preto sa tieto metódy niekedy označujú ako metódy s vol'nými rozdeleniami. Neparametrické metódy pracujú s početnost’ami (napr. chí-kvadrát test nezávislosti), alebo s poradovými číslami, ktoré boli pridelené pôvodným údajom (napr. Kruskal-Wallisov test).

\footnotetext{
* Ing. Alena Košt’álová, PhD., Žilinská univerzita v Žiline, FPEDAS, Katedra spojov, Univerzitná 8215/1, 01026 Žilina, tel.: +421 41513 3143, e-mail: Alena.Kostalova@fpedas.uniza.sk

* doc. Ing. Ol'ga Zajasenská, CSc., Žilinská univerzita v Žiline, FPEDAS, Katedra spojov, Univerzitná 8215/1, 01026 Žilina, tel.: +421 415133138
} 
Predtým, ako sa budeme venovat' metóde testovania nezávislosti medzi hodnotami dvoch kvalitatívnych znakov štatistického súboru, je potrebné ozrejmit' metódu jednostupňového a dvojstupňového triedenia štatistického súboru. Výsledky triedenia pomocou týchto metód sú totiž východiskom metódy testovania nezávislosti.

\section{Metóda jednostupňového triedenia štatistického súboru}

Pri zameraní sa na jeden znak štatistického súboru je hlavným nástrojom analýzy jeho hodnôt jednostupňové triedenie. Úlohou jednostupňového triedenia je získat' absolútne alebo relatívne početnosti výskytu jednotlivých hodnôt. Kumulatívne početnosti pri nominálnych znakoch vzhl'adom na neusporiadatel'nost' ich hodnôt nemajú zmysel, taktiež nelogicky pôsobí priemerná hodnota kvalitatívneho znaku [2].

\section{Metóda dvojstupňového triedenia štatistického súboru}

Širšie možnosti poskytuje analýza hodnôt dvoch nominálnych (alebo ordinárnych) znakov, ich výskytu a vzájomnej závislosti použitím dvojstupňového triedenia. Jeho výsledkom sú kontingenčné tabul'ky. Kontingenčná tabul'ka obsahuje [2]:

$\checkmark$ legendu, kde sú jednotlivé varianty znaku A (označenie je $\mathbf{a}_{\mathbf{i}}$, pre i $=1,2, \ldots, \mathrm{r}$ ),

$\checkmark$ hlavičku, kde sú jednotlivé varianty znaku B (označenie je $\mathbf{b}_{\mathbf{j}}$, pre j $=1,2, \ldots, \mathrm{s}$ ),

$\checkmark$ vlastné pole tabul'ky, do ktorého sa zapisujú tzv. simultánne (združené) početnosti, ktoré vyjadrujú, kol'kokrát sa v súbore vyskytujú kombinácie variantov oboch znakov, teda výsledky dvojstupňového triedenia (označenie združených početností je $\left(\mathbf{a}_{\mathbf{i}} \mathbf{b}_{\mathbf{j}}\right)$ ),

$\checkmark$ posledný riadok, $v$ ktorom sú súčty stĺpcových združených početností, tzv. marginálne početnosti (označenie je $\left(\mathbf{a}_{\mathbf{i}}\right)$ ),

$\checkmark$ posledný stípec v ktorom sú súčty riadkových združených početností, tzv. marginálne početnosti (označenie je $\left(\mathbf{b}_{\mathbf{j}}\right)$ ),

$\checkmark$ priesečník posledného riadku a posledného stípca, kde je rozsah súboru (označenie je n).

Tabul'ka 1. Dvojrozmerné rozdelenia združených početností

\begin{tabular}{|c|c|c|c|c|c|c|c|}
\hline \multirow{2}{*}{$\mathrm{A}$} & \multicolumn{6}{|c|}{ B } & \multirow{2}{*}{$\left(a_{i}\right)$} \\
\hline & $\mathrm{b}_{1}$ & $\mathrm{~b}_{2}$ & $\ldots$ & $b_{j}$ & $\ldots$ & $b_{s}$ & \\
\hline$a_{1}$ & $\left(a_{1} b_{1}\right)$ & $\left(a_{1} b_{2}\right)$ & $\ldots$ & $\left(a_{1} b_{j}\right)$ & $\ldots$ & $\left(a_{1} b_{s}\right)$ & $\left(a_{1}\right)$ \\
\hline $\mathrm{a}_{2}$ & $\left(a_{2} b_{1}\right)$ & $\left(a_{2} b_{2}\right)$ & $\ldots$ & $\left(a_{2} b_{j}\right)$ & $\ldots$ & $\left(a_{2} b_{s}\right)$ & $\left(a_{2}\right)$ \\
\hline$\ldots$ & $\ldots$ & ... & $\ldots$ & $\ldots$ & $\ldots$ & $\ldots$ & ... \\
\hline $\mathrm{a}_{\mathrm{i}}$ & $\left(a_{i} b_{1}\right)$ & $\left(a_{i} b_{2}\right)$ & $\ldots$ & $\left(a_{i} b_{j}\right)$ & $\ldots$ & $\left(a_{i} b_{s}\right)$ & $\left(a_{i}\right)$ \\
\hline$\ldots$ & $\ldots$ & $\cdots$ & $\cdots$ & $\ldots$ & $\cdots$ & $\cdots$ & $\cdots$ \\
\hline $\mathrm{a}_{\mathrm{r}}$ & $\left(a_{r} b_{1}\right)$ & $\left(a_{r} b_{2}\right)$ & $\ldots$ & $\left(a_{r} b_{j}\right)$ & $\ldots$ & $\left(a_{r} b_{s}\right)$ & $\left(a_{r}\right)$ \\
\hline$\left(b_{j}\right)$ & $\left(b_{1}\right)$ & $\left(b_{2}\right)$ & $\ldots$ & $\left(b_{j}\right)$ & $\ldots$ & $\left(b_{s}\right)$ & $\mathrm{n}$ \\
\hline
\end{tabular}

Zdroj: PACÁKOVÁ, V. a kol.: Štatistika pre ekonómov. [3]

Simultánne (združené) početnosti $\left(\mathbf{a}_{\mathbf{i}} \mathbf{b}_{\mathbf{j}}\right)$ sú v prvom rade absolútne početnosti, ktoré udávajú, kol'ko jednotiek zo súboru má súčasne i-tu hodnotu riadkovej premennej A a zároveň j-tu hodnotu stípcovej premennej B. Jednotlivé políčka tabul'ky môžu obsahovat' aj relatívne početnosti $\mathbf{f}_{\mathbf{i}}$, ktoré môžu mat' rozličný základ. Môžu sa počítat' ako: 
a) podiely z celkového rozsahu súboru $\mathbf{n}$, teda podl'a vzt'ahu:

$$
\mathbf{f}_{\mathbf{i}}=\left(\mathbf{a}_{\mathbf{i}} \mathbf{b}_{\mathbf{j}}\right) / \mathbf{n} \text {, }
$$

b) relatívne stĺpcové početnosti podl'a vzt'ahu:

$$
\mathbf{f}_{\mathbf{i}}=\left(\mathbf{a}_{\mathbf{i}} \mathbf{b}_{\mathbf{j}}\right) /\left(\mathbf{b}_{\mathbf{j}}\right) \text {, }
$$

c) relatívne riadkové početnosti podl'a vzt'ahu:

$$
\mathbf{f}_{\mathbf{i}}=\left(\mathbf{a}_{\mathbf{i}} \mathbf{b}_{\mathbf{j}}\right) /\left(\mathbf{a}_{\mathbf{i}}\right) \text {. }
$$

Riadkové a stĺpcové relatívne početnosti nazývame aj podmienené relatívne početnosti. Pri ich použití vzniká niekol'ko problémov [2]. Najviac informácií sa získa, ak v jednotlivých políčkach tabul'ky budú súčasne uvádzané tak absolútne početnosti, ako aj celkové, riadkové a stĺpcové relatívne početnosti. Výhodou je úplná informovanost'. Nevýhodou je, že $\mathrm{v}$ takejto koncentrovanej podobe je príliš vel'a informácií a čast' prezentovaného obsahu sa môže v tejto „hmle“ početností strácat'. Použitie len niektorých $\mathrm{z}$ relatívnych početností určuje, čo chceme prezentáciou výsledkov dvojstupňového triedenia získat', či zdôraznit'.

\section{Testovanie nezávislosti medzi hodnotami dvoch znakov}

Na skúmanie vzt’ahov medzi štatistickými znakmi sa využívajú metódy podl’a toho, či ide o kvantitatívne, alebo kvalitatívne štatistické znaky. Pri kvalitatívnych znakoch sa na skúmanie vzt’ahov medzi nimi využíva metóda nazývaná meranie asociácie. Pri analýze súboru štatistických jednotiek na základe početností výskytu možných dvojíc hodnôt dvoch nominálnych alebo ordinárnych znakov A a B nastáva dôležitá otázka [2]:

$\checkmark$ či medzi hodnotami týchto kvalitatívnych znakov je nejaká závislost', asociácia (t.j., či s výskytom určitých hodnôt znaku A môžeme predpokladat' výskyt niektorých hodnôt druhého znaku B),

$\checkmark$ alebo či hodnoty týchto kvalitatívnych znakov sú nezávislé (výskyt hodnôt znaku A nepredurčuje výskyt hodnôt druhého znaku B).

Ak takáto závislost' neexistuje, znamená to, že ak pri štatistickej jednotke poznáme hodnotu znaku A, nedáva nám to žiadnu informáciu o možnej hodnote znaku B pri tejto jednotke. Podkladom pre skúmanie asociácie sú asociačné, resp. kontingenčné tabul'ky a následne pre súhrnné testovanie existencie štatisticky významného vzt’ahu medzi kvalitatívnymi znakmi sa používa $\chi^{2}$ - štvorcová kontingencia [4].

Pri testovaní nezávislosti medzi hodnotami dvoch kvalitatívnych znakov je postup rozdelený do štyroch krokov. Prvým krokom je formulovanie hypotézy $\mathrm{H}_{0}$ oproti alternatívnej hypotéze $H_{1}$. Druhým krokom je stanovenie hladiny významnœstiTrefm krokom je výpočet testovacej štatistiky a pravdepodobnosti. Štvrtým krokom je porovnanie vypočítanej hodnoty $\chi^{2} \mathrm{~s}$ kritickou hodnotou a prijatie štatistického rozhodnutia.

\section{1. krok - Formulovanie hypotéz}

$H_{0}$ : medzi hodnotami znakov A a B nie je závislost' (nie je asociácia)

$H_{1}$ : medzi hodnotami znakov A a B je závislost' (je asociácia)

Konečným ciel'om väčšiny štatistických testov je zhodnotenie vzt'ahu medzi premennými. Nulová hypotéza vyjadruje nezávislost' premenných. Oproti tomu alternatívna hypotéza, ktorej pravdivost' väčšinou chceme dokázat', najčastejšie vyjadruje štatistickú závislost' premenných. Pravdivost' alternatívnej hypotézy sa dokazuje vždy iba nepriamo a to 
tak, že ukážeme, že nulová hypotéza je nepravdepodobná a alternatívna (jediná zostávajúca) je teda pravdepodobná.

Nezávislost' je overovaná chí-kvadrát testom. Podl'a A. Parasuramana sa chí-kvadrát test používa na zistenie (sprostredkujúci prameň [5]):

$\checkmark$ či sa skúmané rozdelenie početností odpovedí nominálne škálovanej premennej štatisticky významne odlišuje od očakávaného rozdelenia,

$\checkmark$ či možno rozdelenie respondentov z hl'adiska triedenia podl’a určitých kategórií považovat' za zhodné s rozdelením základného súboru.

Chí-kvadrát rozdelenie má prvoradý význam pri analýze závislosti v asociačných a kontingenčných tabul'kách [2]. Najčastejšou situáciou použitia chí-kvadrát rozdelenia je testovanie zhody tabul'ky s niektorým teoretickým modelom. Ide o porovnávanie empirických (nameraných) početností $\left(\mathbf{a}_{\mathbf{i}} \mathbf{b}_{\mathbf{j}}\right)$ a teoretických početností $\left(\mathbf{a}_{\mathbf{i}} \mathbf{b}_{\mathbf{j}}\right)_{\mathbf{0}}$, teda takých, aké by mali empirické početnosti byt', keby boli znaky A a B nezávislé. Pri určovaní teoretických početností vychádzame $\mathrm{z}$ vety o nezávislosti náhodných javov A a B [4]:

$$
\mathbf{P}(\mathbf{A} \cap \mathbf{B})=\mathbf{P}(\mathbf{A}) * \mathbf{P}(\mathbf{B}) \text {. }
$$

Ak sú znaky A a B nezávislé, potom platí:

$$
\mathbf{P}\left(\mathbf{a}_{\mathbf{i}} \mathbf{b}_{\mathbf{j}}\right)=\mathbf{P}\left(\mathbf{a}_{\mathbf{i}}\right) * \mathbf{P}\left(\mathbf{b}_{\mathbf{j}}\right) \text {. }
$$

Na základe relatívnych početností:

$$
\frac{\left(a_{i} b_{j}\right)_{0}}{n}=\frac{\left(a_{i}\right)}{n} * \frac{\left(b_{j}\right)}{n}
$$

odhadneme teoretické početnosti $\left(\mathbf{a}_{\mathbf{i}} \mathbf{b}_{\mathbf{j}}\right)_{\mathbf{0}}$ :

$$
\left(a_{i} b_{j}\right)_{0}=\frac{\left(a_{i}\right)^{*}\left(b_{j}\right)}{n}
$$

\section{2. krok - Stanovenie hladiny významnosti $\alpha$}

Hladina významnosti je pravdepodobnost' tzv. chyby prvého druhu, ktorú urobíme ak zamietneme nulovú hypotézu, ktorá v skutočnosti platí. Teda ak dospejeme k záveru, že medzi premennými existuje vzt’ah, pričom medzi nimi vzt'ah nie je. Chybu prvého druhu môžeme zmenšit', ak zaa zvolíme menšie číslo. Tým však umožňujeme prijatie hypotézy a súčasne väčšmi umožníme vznik tzv. chyby druhého druhu. Táto spočíva $v$ tom, že nezamietneme nesprávnu hypotézu. Stanovenie hladiny významnosti je teda akýmsi kompromisom medzi týmito dvoma druhmi chýb a jeho vol’ba závisí od charakteru testovaných skutočností, od skúseností a pod. [6]

Alfa $(\alpha)$ sa tradične stanovuje na hodnotu $5 \%(=0,05)$, alebo $1 \%(=0,01)$. Odchýlky, ktoré sa vyskytujú s pravdepodobnost'ou menšou ako je zvolená hladina významnosti, sa nazývajú štatisticky významné (signifikantné) pri zvolenej hladine významnosti.

\section{3. krok - Výpočet testovacej štatistiky $\chi^{2}$ a pravdepodobnosti}

$$
\chi^{2}=\sum_{i=1}^{r} \sum_{j=1}^{s} \frac{\left[\left(a_{i} b_{j}\right)-\left(a_{i} b_{j}\right)_{0}\right]^{2}}{\left(a_{i} b_{j}\right)_{0}}
$$

Pomocou testovacej štatistiky podl'a vzt'ahu (8) sa zistí štatistická hodnota testu chí-kvadrát pre empirické a teoretické početnosti. Vypočíta sa zo vzorky, ktorá má za predpokladu pravdivosti nulovej hypotézy príslušné rozdelenie pravdepodobnosti 
(chí-kvadrát). Okrem testovacej štatistiky sa vyčísl'uje aj pravdepodobnost', tzv. P-hodnota (Probability Level), pre ktorú platí nasledovné:

$\checkmark$ predstavuje pravdepodobnost', že testovacia štatistika za predpokladu nulovej hypotézy dosiahne prinajmenšom tak extrémnu hodnotu ako je hodnota vypočítaná zo vzorky,

$\checkmark$ je to pravdepodobnost', že vzt’ah zistený zo získaných údajov je iba dôsledkom „nešt’astne zvolenej““ vzorky a ak by bola vybratá d’alšia náhodná vzorka, vzt’ah z nových údajov by nemusel byt' zistený,

$\checkmark$ je to najnižšia hodnota hladiny významnosti, ktorá vedie k zamietnutiu nulovej hypotézy,

$\checkmark$ je to odhadovaná pravdepodobnost' zamietnutia pravdivej nulovej hypotézy,

$\checkmark$ čím menšia je P-hodnota, tým viac možno byt' presvedčený, že nulová hypotéza nie je pravdivá a mala by byt’ zamietnutá.

K. Pearson, ktorý ako prvý navrhol testovaciu štatistiku $\chi^{2}$ (sprostredkujúci prameň [2]), dokázal, že ak teoretické hodnoty $\left(\mathbf{a}_{\mathbf{i}} \mathbf{b}_{\mathbf{j}}\right)_{\mathbf{0}}$ nebudú príliš malé (vyžaduje sa $\left(\mathrm{a}_{\mathrm{i}} \mathrm{b}_{\mathbf{j}}\right)_{0}>5$ ), rozdelenie premennej $\chi^{2}$ bude približne takým istým ako chí-kvadrát rozdelenie, pričom počet stupňov vol'nosti d sa rovná:

$$
\mathbf{d}=(\mathbf{r}-1) *(s-1),
$$

kde $\mathbf{r}$ je počet riadkov a s je počet stípcov kontingenčnej tabul'ky (znak A má $\mathbf{r}$ - úrovní, obmien a znak B má s - úrovní, obmien). Podl'a W. G. Cochrana [7], [8], [9], teoretických početností menších ako 5 môže byt' najviac $20 \%$, ale aj tieto musia byt' väčšie ako 1:

$$
\mathbf{P}\left[\left(\mathbf{a}_{\mathbf{i}} \mathbf{b}_{\mathbf{j}}\right)_{0}<5\right] \leq 0,2 \wedge\left(\mathbf{a}_{\mathbf{i}} \mathbf{b}_{\mathbf{j}}\right)_{0}>\mathbf{1}
$$

V prípade, že podmienka (10) nie je splnená, je potrebné dodatočne nájst' príbuzné triedy (do ktorých bol štatistický súbor roztriedený), ktoré spolu vecne súvisia a ktoré by bolo možné zlúčit', čím sa následne zmení aj počet stupňov vol'nosti. [10]

Podmienka (10) je predpokladom, alebo tiež obmedzením pre použitie Pearsonovho chí-kvadrát testu a výpočet testovacej štatistikyx ${ }^{2} \mathrm{v}$ tabul'kách s viac ako 2 riadkami a viac ako 2 stĺpcami. Pre použitie Pearsonovho chí-kvadrát testu v tabul'kách s rozmermi 2 x 2 platia nasledujúce obmedzenia [7], [11]:

$\checkmark$ všetky teoretické početnosti musia byt' väčšie alebo rovné 10 ,

$\checkmark$ ak je niektorá z teoretických početností menšia ako 10 , ale väčšia alebo rovná 5 , niektorí autori odporúčajú použit' Yatesovu korekciu spojitosti ${ }^{1}$,

$\checkmark$ ak je niektorá z teoretických početností menšia ako 5, použije sa niektorý z iných testov (napr. Fisherov exaktný test pre kontingenčné tabul'ky s rozmermi 2 x 2).

\section{4. krok - Prijatie štatistického rozhodnutia o hypotéze $H_{0}$ :}

Pri prijímaní štatistického rozhodnutia o hypotéze $H_{0}$ je potrebné sa riadit' nerovnost'ou medzi vypočítanou hodnotou testovacieho kritéria a príslušnou kritickou hodnotou, ktorou je vymedzená kritická oblast' pre chi-kvadrát:

$$
\chi^{2} \geq \chi_{1-\alpha}^{2}[(r-1) *(s-1)]
$$

\footnotetext{
${ }^{1}$ Yatesova korekcia spojitosti spočíva v tom, že pri výpočte testovacej štatistiky $\chi^{2}$ podl’a vzt'ahu (8), sa pred umocnením rozdielu empirickej a teoretickej početnosti odčíta hodnota 0,5 od absolútnej hodnoty tohto rozdielu [12], (táto korekcia je však kontroverzná a neodporúčajú ju všetci autori).
}

$$
\chi^{2}(\text { Yates })=\sum_{i=1}^{r} \sum_{j=1}^{s} \frac{\left[\left|\left(a_{i} b_{j}\right)-\left(a_{i} b_{j}\right)_{0}\right|-0,5\right]^{2}}{\left(a_{i} b_{j}\right)_{0}}
$$


Pri porovnávaní vypočítanej hodnoty testovacieho kritéria s príslušnou kritickou hodnotou $\chi^{2}$ pre hladinu významnosti $\alpha(\alpha=0,05)$ so stup̌ami vol'nosti $\mathrm{d}=(\mathrm{r}-1) *(\mathrm{~s}-1)$, ktorá je tabelovaná, môžu nastat' dva prípady [6]:

a) Vypočítaná hodnota testovacieho kritéria je väčšia alebo rovná ako kritická hodnota, t.j. vzt’ah (12) platí. To však znamená, že nastal prípad, ktorý sme za predpokladu správnosti nulovej hypotézy očakávali s takou malou pravdepodobnost'ou $(\alpha=0,05)$, že ho môžeme považovat' za takmer nemožný. Ak aj napriek malej pravdepodobnosti nastal, predpokladáme, že testovaná odchýlka nemá charakter náhodný a že teda jej vel'kost' je výrazom skutočného rozdielu medzi vlastnost’ami, vyjadrenými porovnávanými štatistickými charakteristikami. Preto nulovú hypotézu zamietame pri zvolenej hladine významnosti (hypotéza $\mathrm{H}_{1}$ je preukázaná) a tvrdíme, že rozdiel medzi početnost'ami zistenými vo vzorke a očakávanými početnost’ami je príliš vel'ký na to, aby bol iba dôsledkom náhodného výberu. Sledovaný rozdiel je štatisticky významný. Medzi premennými teda existuje vzt’ah. Čím je $\alpha$ mešie, tým má zamietnutie $\mathrm{H}_{0}$ väčší význam, tzn. jej zamietnutie je zriedkavejšie nesprávne.

b) Vypočítaná hodnota testovacieho kritéria je menšia ako kritická hodnota, t. j. vzt'ah (12) neplatí. To znamená, že ide o prípad, ktorý sme za predpokladu, že nulová hypotéza je správna, očakávali s takou vel'kou pravdepodobnost'ou $(0,95)$, že jeho výskyt môžeme považovat' za istý. Predpokladáme preto, že testovaná odchýlka má charakter náhodný. Nulovú hypotézu v tomto prípade nemožno zamietnut' pri zvolenej hladine významnosti a tvrdíme, že rozdiel medzi početnost’ami zistenými vo vzorke a očakávanými početnost'ami môže byt' dôsledkom náhodného výberu. Sledovaný rozdiel nie je štatisticky významný. To však neznamená, že nulová hypotéza je správna. Správne rozhodnutie je, že nemáme dostatočné dôkazy na to, aby sme nulovú hypotézu zamietli. Teda nemáme dostatok dôkazov na to, aby sme mohli tvrdit', že medzi premennými existuje vzt'ah. Hypotézu $\mathrm{H}_{1}$ možno alebo považovat' za nepreukázanú a zdržat' sa záveru o testovanej $\mathrm{H}_{0}$, alebo možno $\mathrm{H}_{0}$ prijat', čo však vyžaduje mat' pod kontrolou pravdepodobnost' chyby II. druhu.

Na testovanie nezávislosti medzi hodnotami dvoch kvalitatívnych znakov štatistického súboru hodnôt získaných marketingovým prieskumom je vhodné využit' funkciu CHITEST v prostredí Microsoft Excel. Výsledkom funkcie CHITEST je hodnota pravdepodobnosti chí-kvadrát rozdelenia pre danú testovaciu štatistiku a príslušný počet stupňov vol'nosti (P-hodnota), ktorá bude využitá na rozhodnutie o hypotéze $\mathrm{H}_{0}$ [2]:

$\checkmark \quad$ ak je hodnota pravdepodobnosti chí-kvadrát rozdelenia $\mathbf{v}$ intervale od 0 po $\boldsymbol{\alpha}$, (P-hodnota $<\alpha$ ), potom hypotézu $\mathbf{H}_{0}$ zamietame voči príslušnej alternatívnej hypotéze; tj. medzi znakmi A a B je štatisticky významná závislost' (asociácia),

$\checkmark \quad$ ak je hodnota pravdepodobnosti chí-kvadrát rozdelenia $\mathbf{v}$ intervale od $\boldsymbol{\alpha}$ po 1 , (P-hodnota $\geq \alpha$ ), potom hypotézu $\mathbf{H}_{0}$ reprezentujúcu nezávislost' znakov A a B nemožno zamietnut'.

V nasledujúcej tabul'ke 2. sú uvedené situácie, ktoré môžu nastat' pri testovaní hypotéz v súvislosti s výskytom chyby I. a II. druhu. 
Tabul'ka 2. Situácie, ktoré môžu nastat' pri testovaní hypotéz

\begin{tabular}{|l|l|l|}
\hline \multirow{2}{*}{ Skutočnost' } & \multicolumn{2}{|c|}{ Rozhodnutie } \\
\cline { 2 - 3 } & $\mathrm{H}_{0}$ nezamietnutá & $\mathrm{H}_{0}$ zamietnutá \\
\hline $\mathrm{H}_{0}$ je pravdivá & Správne rozhodnutie $(\mathrm{p}=1-\alpha)$ & Chyba I. druhu $(\mathrm{p}=\alpha)$ \\
\hline $\mathrm{H}_{0}$ je nepravdivá & Chyba II. druhu $(\mathrm{p}=\beta)$ & Správne rozhodnutie $(\mathrm{p}=1-\beta)$ \\
\hline
\end{tabular}

Zdroj: RIMARČ́́K, M.: Testy štatistických hypotéz [13]

Vysvetlivky: $\mathrm{p}$... pravdepodobnost' nastatia danej situácie

$\alpha$... hladina významnosti (Significance Level)

$1-\alpha \ldots$ spol'ahlivost' (Confidence Level)

$1-\beta \ldots$ sila testu (Power)

\section{Miery stupňa závislosti (asociácie) medzi dvomi znakmi}

Pomocou chí-kvadrát testu je možné získat' informáciu, či vzájomnú závislost' medzi hodnotami kvalitatívnych znakov A a B je možné považovat' za štatisticky významnú alebo nie. V prípade štatistickej významnosti tejto závislosti (asociácie) však stupeň tejto závislosti možno hodnotit' len nepriamo, pomocou hodnoty pravdepodobnosti chí-kvadrát rozdelenia (výsledok funkcie CHITEST). Cím je hodnota pravdepodobnosti bližšia k nule, tým je stupeň vzájomnej závislosti vyšší.

Autori Chajdiak - Komorník - Komorníková [2] uvádzajú nasledovné štatistické miery vzájomnej závislosti nominálnych znakov, ktoré sú odvodené od vypočítanej hodnoty testovacieho kritéria - $\chi^{2}$ hodnoty:

Phi koeficient (Phi je anglickým prepisom gréckeho písmena $\varphi$ )

- predstavuje druhú odmocninu $\mathrm{z}$ pomeru $\chi^{2}$ hodnoty k rozsahu súboru n,

- nadobúda hodnoty, ktoré sa rovnajú, alebo sú vyššie ako 0 (nevýhodou Phi koeficientu je práve neexistencia horného ohraničenia),

- využíva sa len v tabul'kách s rozmermi 2 x 2 [14],

- interpretácia - čím viac sa jeho hodnota blíži k 0, tým je vyšší stupeň nezávislosti medzi hodnotami znakov A a B.

$$
\text { Phi koeficient }=\sqrt{\frac{\chi^{2}}{n}}
$$

\section{Kontingenčný koeficient (Contingency Coefficient, Pearsonov koeficient C)}

- predstavuje druhú odmocninu z pomeru $\chi^{2}$ hodnoty k súčtu $\chi^{2}$ hodnoty a rozsahu súboru n,

- nadobúda hodnoty z intervalu $<0,1$ ),

- predstavuje upravený Phi koeficient určený pre použitie v tabul'kách s rozmermi väčšími ako je 2 × 2 ,

- jeho maximum sa blíži, ale nikdy úplne nedosiahne hodnotu 1, iba vo vel'kých tabul'kách, preto ho niektorí autori odporúčajú iba pre tabul'ky s rozmermi 5 x 5 a väčšie [14] (jeho maximálna hodnota v tabul'ke s rozmermi 2 x 2 je 0,707),

- interpretácia - čím viac sa jeho hodnota blíži k 0, tým je vyšší stupeň nezávislosti medzi hodnotami znakov A a B.

$$
C=\sqrt{\frac{\chi^{2}}{\chi^{2}+n}}
$$




\section{$>$ Cramerovo V (Cramer's V)}

- vypočíta sa ako druhá odmocnina $\mathrm{z}$ pomeru $\chi^{2}$ hodnoty $\mathrm{k}$ súčinu rozsahu súboru $\mathrm{n}$ a hodnoty h; kde h je minimum z čísel (r - 1) a (s - 1),

- nadobúda hodnoty $\mathrm{z}$ intervalu $<0,1>$,

- je to najčastejšie používaná miera asociácie, pretože nadobúda hodnoty od 0 (žiadny vzt'ah) po 1 (dokonalý vzt'ah) bez ohl'adu na vel'kost' tabul'ky [14],

- má tendenciu dosahovat' nižšiu hodnotu ako Phi koeficient alebo kontingenčný koeficient,

- interpretácia - čím viac sa jeho hodnota blíži k 0, tým je vyšší stupeň nezávislosti medzi hodnotami znakov A a B.

$$
V=\sqrt{\frac{\chi^{2}}{n * h}}
$$

\section{Čuprovov koeficient [3]}

- vypočíta sa ako odmocnina z pomeru priemernej $\chi^{2}$ hodnoty (priemernej štvorcovej kontingencie) k odmocnine súčinu čísel ( $\mathrm{r}-1)$ a ( $\mathrm{s}-1)$, kde $\mathrm{r}$ je počet obmien znaku A a s je počet obmien znaku B,

- nadobúda hodnoty $\mathrm{z}$ intervalu $<0,1>$,

- hodnotu 1 dosahuje v štvorcových tabul'kách, kde sú riadkové marginálne početnosti identické so stĺpcovými marginálnymi početnost’ami [14],

- využíva sa zriedkavo a nie je podporovaný základným štatistickým softvérom,

- interpretácia - čím viac sa jeho hodnota blíži k 0, tým je vyšší stupeň nezávislosti medzi hodnotami znakov A a B.

$$
\tau=\sqrt{\frac{\phi^{2}}{\sqrt{(r-1)^{*}(s-1)}}}, \text { kde } \phi^{2}=\frac{\chi^{2}}{n}
$$

Pri zist'ovaní stupňa vzájomnej závislosti medzi hodnotami dvoch kvalitatívnych znakov je vhodné, v zmysle vyššie spomenutých obmedzení, používat' jednotlivé miery asociácie nasledovne ${ }^{2}$ :

$>$ Phi koeficient - iba v prípadoch, ked' má tabul'ka rozmery 2 × 2,

$>$ Kontingenčný koeficient (Pearsonov) - pre tabul'ky s rozmermi 5 x 5 a väčšie,

$>$ Cramerovo V - pre tabul'ky s rozmermi väčšími ako 2 × 2 ale menšími ako 5 x 5 ,

$>$ Čuprovov koeficient - iba pre štvorcové tabul'ky, kde sú riadkové marginálne početnosti identické so stípcovými marginálnymi početnost’ami.

Pri interpretácii týchto mier asociácie možno použit' škálu, ktorú zaviedol Cohen (1988) pre korelačný koeficient $(0,1$ až 0,3 značí slabú koreláciu; 0,3 až 0,5 značí strednú koreláciu a 0,5 až 1,0 značí silnú koreláciu [15]). Nie je však nevyhnutné túto škálu striktne dodržiavat', a to najmä v sociálnych vedách.

Interval 0,5 až 1,0 vyjadrujúci silnú koreláciu je pri zist'ovaní stupňa vzájomnej závislosti medzi hodnotami dvoch kvalitatívnych znakov vel'mi široký a preto je vhodné rozdelit' ho do viacerých menších intervalov, ako je uvedené v tabul'ke 3. [16]

\footnotetext{
${ }^{2}$ všetky spomenuté miery asociácie sú symetrické, tzn. pri ich výpočte nie je dôležité, ktorý zo znakov A a B je stĺpcovou premennou
} 
Tabul'ka 3. Interpretácia miery stupňa závislosti medzi dvomi znakmi

\begin{tabular}{|c|c|}
\hline Hodnota miery stupňa závislosti & Stupeň závislosti \\
\hline 0,0 & úplná nezávislost' \\
\hline $0,0-0,1$ & triviálna závislost' \\
\hline $0,1-0,3$ & slabá závislost' \\
\hline $0,3-0,5$ & stredná závislost' \\
\hline $0,5-0,7$ & silná závislost' \\
\hline $0,7-0,9$ & vel'mi silná závislost' \\
\hline $0,9-1,0$ & takmer úplná závislost' \\
\hline 1,0 & úplná závislost' \\
\hline
\end{tabular}

Zdroj: Cohen's scale for correlation coefficient. [16]

\section{Záver}

Úlohou marketingového prieskumu je získavat' objektívne, včasné, úplné a spol'ahlivé informácie o skúmanom jave. Pri spracovávaní získaných informácií je možné využit' viaceré metódy. Jednou z nich je aj metóda testovania nezávislosti medzi vybranými dvojicami kvalitatívnych znakov štatistického súboru. V prípade potvrdenia štatisticky významnej závislosti medzi hodnotami týchto znakov sa následne stanovuje stupeň ich vzájomnej závislosti pomocou niektorej miery asociácie, za predpokladu dodržania pravidiel pre ich použitie.

Ak je marketingový prieskum zameraný na využívanie poštových a telekomunikačných služieb, tak ako tomu bolo v prípade riešenia spomínanej dizertačnej práce, je vhodné využit' výsledky testovania nezávislosti aj voblasti marketingovej komunikácie jednotlivých poskytovatel'ov poštových a telekomunikačných služieb za účelom zvýšenia kvality týchto služieb.

\section{Literatúra}

[1] RIMARČÍIK, M. Testy normality. [online]. [cit. 2009-05-07]. Dostupné na internete: $<$ http://rimarcik.com/navigator/normal.html>.

[2] CHAJDIAK, J. - KOMORNÍK, J. - KOMORNÍKOVÁ, M. Štatistické metódy. Bratislava : STATIS, 1999. ISBN 80-85659-13-1.

[3] PACÁKOVÁ, V. a kol. Štatistika pre ekonómov. Bratislava : Edícia EKONÓMIA, 2003. ISBN 80-89047-74-2.

[4] SOJKOVÁ, Z. Materiál na prednášky z predmetu Ekonomická štatistika. Slovenská pol'nohospodárska univerzita Nitra, Fakulta ekonomiky a manažmentu, Katedra štatistiky a operačného výskumu. [online]. [cit. 2009-04-07]. Dostupné na internete: $<$ http://www.fem.uniag.sk/ACADEMIC/depart/ksov/predmety/statistika>.

[5] LESÁKOVÁ, D.- RAJT, Š. Marketingové analýzy a prognózy. Bratislava : EKONÓM, 1996. ISBN 80-225-0743-1.

[6] LINCZÉNYI, A. Inžinierska štatistika. Bratislava : ALFA, 1974. 63-025-74.

[7] COCHRAN, W. G. Some methods for strengthening the common $\chi^{2}$ tests. In Biometrics, 1954. 10: pp 417-451.

[8] Pearson's chi-square test. [online]. [s.a.]. [cit. 2009-08-28]. Dostupné na internete: $<$ http://en.wikipedia.org/wiki/Pearson's_chi-square_test>.

[9] YATES, D. - MOORE, D. - McCABE, G. The Practice of Statistics. 1st Ed. New York : W.H. Freeman, 1999. 
[10] HINDLS, R. - HRONOVÁ, S. - SEGER, J. Statistika pro ekonomy. Druhé vydání. Praha : Professional Publishing, 2002. ISBN 80-86419-30-4.

[11] COCHRAN, W. G. The $\chi^{2}$ test of goodness of fit. In Annals of Mathematical Statistics, 1952. 25:315-345.

[12] YATES, F. Contingency table involving small numbers and the $\chi^{2}$ test. In Supplement to the Journal of the Royal Statistical Society. JSTOR Archive for the journal, 1934. 1(2): 217-235.

[13] RIMARČÍK, M. Testy štatistických hypotéz. [online]. [cit. 2009-05-07]. Dostupné na internete: <http://rimarcik.com/navigator/hypotezy.html>.

[14] Nominal Association: Phi, Contingency Coefficient, Tschuprow's T, Cramer's V, Lambda, Uncertainty Coefficient. [online]. [s.a.]. [cit. 2009-08-28]. Dostupné na internete: <http://faculty.chass.ncsu.edu/garson/PA765/assocnominal.htm>.

[15] COHEN, J. Statistical power analysis for the behavioral sciences. 2nd ed., Hillsdale, New Jersey: Lawrence Erlbaum, 1988.

[16] Cohen's scale for correlation coefficient. [online]. [s.a.]. [cit. 2009-08-31]. Dostupné na internete: <http://www.sportsci.org/resource/stats/effectmag.html>.

[17] KOŠŤÁLOVÁ, A. Marketingový prieskum využívania poštových a telekomunikačných služieb v regionálnom podnikatel'skom prostredi : doktorandská dizertačná práca. Žilina : Žilinská univerzita v Žiline. 2009. 123 s.

[18] PAĎOUROVÁ, A. - KOŠŤÁLOVÁ, A. - PAVLIČKO, M. - ŠVÁBOVÁ, L. Využívanie poštových a telekomunikačných služieb v regionálnom podnikatel'skom prostredí so zameraním na malé a stredné podniky v regióne Žilina : Inštitucionálny projekt č. I16-07140. Žilina : Žilinská univerzita v Žiline, FPEDAS, 2008.

\section{Grantová podpora}

SUROVEC, P. a kol: Socio-ekonomické dáta v prognóze a modelovaní dopravy pri naplńnaní ekonomickej funkcie regiónu. Grantový projekt VEGA MŠ SR a SAV č. 1/0344/08, Žilinská univerzita v Žiline, FPEDAS, 2008.

JANKALOVÁ, M. a kol: Poskytovanie verejnej telefónnej služby a spôsoby jej hodnotenia v procese globalizácie. Grantový projekt VEGA MŠ SR a SAV č.1/0709/08, Žilinská univerzita v Žiline, FPEDAS, 2008. 